HARMATTA JÁNOS

\title{
EGY PALMYRAI FELIRAT DACIÁBÓL
}

Már három-négy évtizede lehet, hogy Czeglédy Károly megmutatta nekem egy három sorból álló felirat fényképét, amelyet egy tudós barátja küldött neki Romániából azzal a kéréssel, hogy határozza meg írását és nyelvét. Elmondása szerint barátja annyit közölt vele, hogy a felirat lelóhelye Szamosújvár (Gherla), ahol a palmyrai ijászok táborának közelében találták. A fényképet küldő tudós szerint a palmyrai ijászoktól más írással írt emlékek maradtak fenn s ezért arra gondolt, hogy esetleg valamilyen kisázsiai nyelven vagy perzsa, párthus, illetve más iráni írással íródott. Czeglédy Károly éppen ezért fordult hozzám, mert azt gondolta, hogy a felirat valóban iráni nyelvú lehet.

A feliratról elsô rátekintésre meg lehetett állapítani, hogy egyetlen ismert középiráni nyelv írásával sem hozható kapcsolatba. Azonban akkoriban már ismertem az alább ismertetett Brigetio-i szír feliratot és annak sajátos kurzív ábécéjét. A Szamosújváron talált felirat írása emlékeztetett erre az arameus eredetú ábécére, ezért úgy túnt, hogy ha ez a feliratos emlék nem lehet palmyrai írásos feljegyzés, akkor valószínúleg szír nyelvemlékkel van dolgunk. Ez annál inkább is lehetségesnek látszott, mert Dáciában nemcsak palmyrai, hanem szír csapatok is állomásoztak. ${ }^{1}$ Véleményemet közöltem Czeglédy Károllyal, aki nem akart a nehezen olvasható felirattal foglalkozni, hanem megkért, hogy kíséreljem meg kibetúzését és értelmezését.

E munkát akkor mindjárt elkezdtem, azonban hamarosan világossá vált, hogy a kurzív szír (esțrangelā) ábécé nem nyújt kellő alapot a Szamosújvárról származó felirat írásjeleinek azonosításához. Így a fényképet egyelőre félretettem s további tanulmányozását arra az időre halasztottam, amikor a Brigetioban talált szír felirat közzétételét már elkészítettem. Ez más feladatok és az élet különböző nehézségei miatt csak nemrégiben történhetett meg. Közben Czeglédy Károly eltávozott közülünk s így már nem lehetett sem azt megállapítani, hogy ki küldte neki a felirat fény-

${ }^{1}$ Makkai László-Mócsy András: Erdély története. I. Budapest 1986. 84 (numerus Surorum sagittariorum, cohors I Tyrorum, cohors I sagittariorum equitata). 


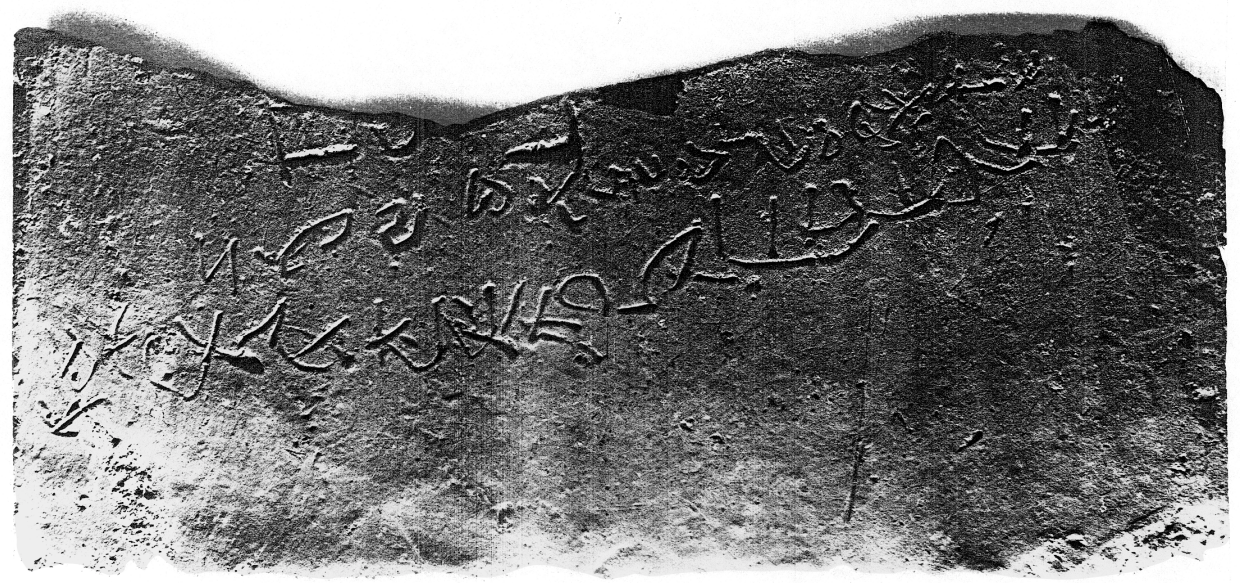

1. kép. A szamosújvári palmyrai felirat

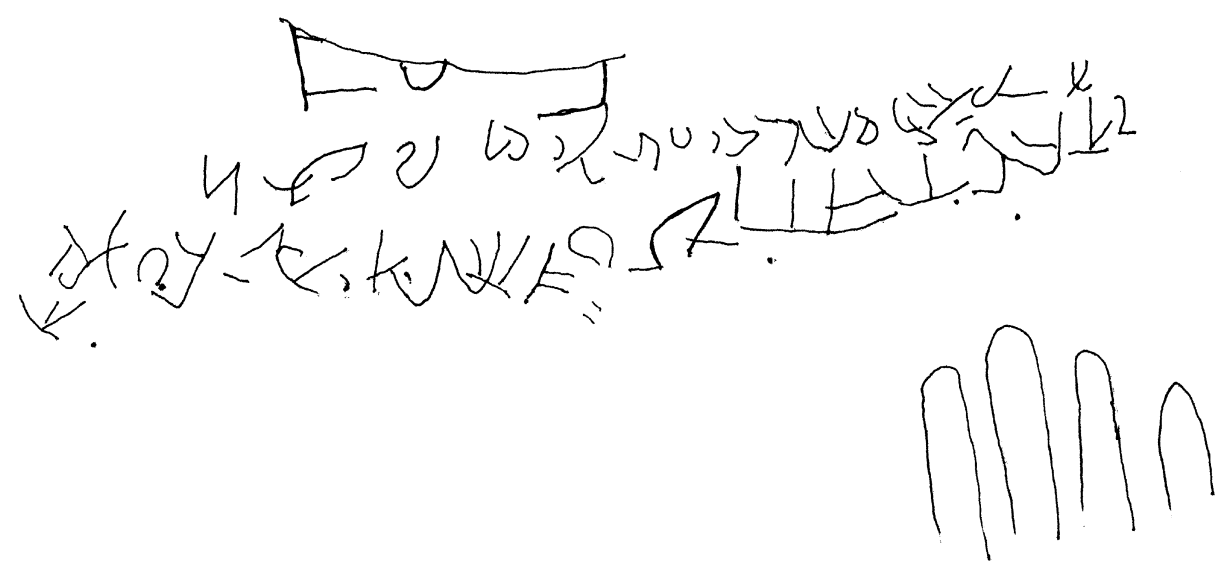

2. kép. A szamosújvári palmyrai felirat autográfiája

képét, sem pedig, milyen leletkörülmények között került napvilágra, melyik múzeumban őrzik, milyen anyagra íródott s melyek a méretei. Ezért legjobb megoldásnak az látszott, ha közzé teszem a felirat olvasására és értelmezésére vonatkozó javaslataimat, amelyek így talán eljuthatnak azokhoz a tudósokhoz, akik Dacia római helyőrségeinek történetével foglalkoznak.

A szamosújvári felirat alaposabb tanulmányozása azonnal nyilvánvalóvá tette, hogy a kurzív szír esțrangelā íráshoz csak annyi köze van, hogy szintén erôsen kurzív 
jellegú, azonban betúformái jelentősen eltérnek annak megfeleló jeleitől (l. írástáblázat). A šinn, a tāv és a semka $\theta$ betúk alakja világosan megmutatta, hogy palmyrai írással van dolgunk s hogy a felirat fényképét küldô tudós nem tudta azonosítani az írást, annak csak az lehetett az oka, hogy a Szamosújváron talált többi palmyrai felirat lapidáris (díszes) palmyrai írással, ez viszont annak kurzív változatával íródott.

\begin{tabular}{|c|c|c|c|c|c|c|c|c|c|c|}
\hline & $S z$ & D 845 & D908 & D) 09 & 15907 & $D 916$ & $P d$ & 1 & $5 S$ & $P K$ \\
\hline , & 千 & $\times T$ & 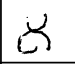 & $x$ & $\pi$ & $N / T$ & б & $\sigma$ & $X Y$ & KK \\
\hline$b$ & $y \mathcal{L}$ & $y$ & $y$ & $y$ & j & $5 \mathrm{~J}$ & $y$ & 3 & 30 & J \\
\hline 8 & $y$ & -1 & $\lambda$ & & + & $\lambda$ & $\alpha$ & & $\lambda$ & $\lambda \lambda$ \\
\hline$d$ & $D_{Y} Y$ & $7 y$ & $y$ & 4 & 4 & 14 & $Y$ & & & 7 \\
\hline$h$ & $K L$ & וֹנ & & 가 & & $\pi \lambda$ & & & & $\lambda=$ \\
\hline$w$ & 2 & 7 & 1 & & 27 & 77 & 9 & & & 1 \\
\hline$z$ & & 1 & & & & 1 & 1 & & & 1 \\
\hline$h$ & N L & $H$ & $H$ & $\mathrm{H}$ & j- & $H$ & iH & $N$ & ji & $H N$ \\
\hline$t$ & 0 & 00 & & $9 \mathrm{~V}$ & & & 3 & & & 60 \\
\hline$y$ & ) & $\cap ?$ & 172 & $7 n$ & 17 & $m^{n} n$ & 0 & $\wedge$ & nn & $3 n$ \\
\hline k & $y$ & $J$ & $y$ & & I & $y$ & $y$ & $J$ & & J J \\
\hline 1 & 52 & j & $y$ & $J$ & $b$ & $J \partial$ & $b$ & J & & b]J \\
\hline$m$ & $E J$ & & sh & $y$ & $\Gamma$ & $\Delta y$ & $S$ & IJ & & $17 \pi$ \\
\hline$n$ & J 15 & 115 & 5 & S & IS & ijj & 33 & $\jmath$ & 3 & 371 \\
\hline 5 & 9 & $\eta$ & & & v & $\eta$ & $y$ & & & y \\
\hline$c$ & $U$ & $1 y$ & $y$ & $y$ & $y$ & $y$ & $y$ & & $>$ & $>$ \\
\hline$P$ & $\checkmark$ & 3 & & & & & 3 & 1 & & 3 \\
\hline 5 & & & $S-1$ & H & $\mathrm{H}$ & & N & & & $H$ \\
\hline$q$ & 5 & 乃 & & I & & & 53 & & & $\Pi \Pi$ \\
\hline$r$ & YY. & 7 & $y$ & 3 & $4 \%$ & 1 & $q$ & 7 & $4 y$ & 7 \\
\hline$\breve{s}$ & $1 E t$ & $\uplus \bullet$ & & 0 & & U & $y$ & $\sigma$ & & と匕 \\
\hline$t$ & 4 & 5 & j & $j$ & ภ & ר) & J7 & $x$ & 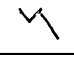 & $4 h$ \\
\hline
\end{tabular}

3. kép. Palmyrai írástáblázat. A rövidítések magyarázata: Sz = Szamosújvár, D 845, D 907, D 908, D 909, D 916 = Dura-Europosban talált palmyrai feliratok, Pd = palmyrai díszírás, I = itáliai palmyrai felirat, SS = South Shields-i palmyrai felirat (Anglia), Pk = palmyrai kurzív írás 
A palmyrai írásnak ez a két fajtája párhuzamosan fejlődött és élt egymás mellett ${ }^{2}$, s ezért hatott is egymásra. ${ }^{3}$ Igy a szóban forgó szamosújvári feliratban is találunk a kurzív mellett lapidáris formákat is (pl. a bēe, dāla $\theta$, kāf esetében). Ez a körülmény és a kurzív írású palmyrai feliratok ${ }^{4}$ kis száma, valamint a palmyrai írásfajták jelformáinak nagy változatossága (l. írástáblázat) nehezíti meg a felirat kibetúzését.

A felirat három sorból áll: az 1. sorba azonban csak három betút véstek be. Ezek nagyobb méretúek, mint a felirat többi betúi. Felsố részük letörött a felirat kővagy agyaglapjának felsô részével együtt, azonban kiegészítésük nem ütközik különösebb nehézségbe és megnyugtatóan azonosíthatók. A 2. sor amely 17 írásjelet tartalmaz, az 1 . sorral azonos magasságban kezdődik, de azután ferdén, kb. $15^{\circ}$-os szögben lefelé halad, hogy az elsố sor alatt elférjen. Ugyanilyen az elhelyezése a 22 betút tartalmazó 3. sornak is. A 2. és a 3. sorban megfigyelhetô, hogy a betúk magassága bal felé haladva növekszik s a sorok végén hozzávetôleg a kétszerese a sorok elején bekarcoltaknak. Az a körülmény, hogy mélyebb bekarcolásoknál a tábla anyaga felgyưrôdött, arra mutat, hogy agyagból készült, s a felirat bekarcolásának időpontjában még elég lágy volt.

A feliratnak következő olvasata javasolható (a palmyrai írás jeleit technikai okokból héber betúkkel helyettesítjük).

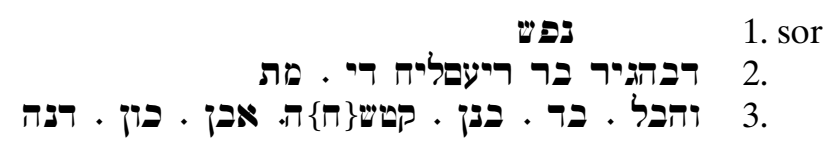

Megjegyzések az olvasáshoz:

1. sor. A nūn-nak és a pē-nek hozzávetóleg a fele, a šinn-nek a negyede tört le, a betúk azonban más kurzív palmyrai feliratok alapján biztosan kiegészíthetők és így a szó olvasata biztos.

2. sor. A רבהדיריר szóban a dāla $\theta$ a palmyrai díszírás betúformáját követi (1. írástáblázat), a bē $\theta$ és a hē erôsen kurzív (a bē $\theta$ dôlési szöge kb. $80^{\circ}$, a hē-é $\mathrm{kb} 45^{\circ}$ ). Erôsen kurzív a gāmal is, a yō $\delta$ és a rēš pedig ligatúrát alkot. Mivel a $y \bar{o} \delta$ a kurzív palmyrai írásban egyébként mindig a megelózó betúvel alkot ligatúrát, az ebben a feliratban megfigyelhetô yō $\delta+$ rēš ligatúra valószínúleg úgy jött létre, hogy a felirat készítôje először kifelejtette a rēš-t s ezt csak akkor vette észre, amikor a következő bē $\theta$ írásjelet már bekarcolta. Így már csak úgy tudta a rēš-t beszúrni, hogy az jobboldalt alul és felül érintkezett a yō $\delta$-dal, baloldalt felül pedig a $b \bar{e} \theta$ jobboldali szárával. A רבהזיר A hely hiánya lehetett az oka annak is, hogy a rēš feje túlságosan rövid lett.

\footnotetext{
${ }^{2}$ F. Rosenthal: Die Sprache der palmyrenischen Inschriften. Leipzig 1936.

${ }^{3}$ F. Rosenthal: i. m. 9.

${ }^{4}$ F. Rosenthal: i. m. 9.
} 
írásképben $\boldsymbol{\Pi} \sim \boldsymbol{\Pi}$ tévesztéssel van dolgunk, amely más palmyrai feliratokban is előfordul. ${ }^{5}$

A ריעםיעליח szóban vagy betúsorrend-tévesztés történt, amennyiben a helyes

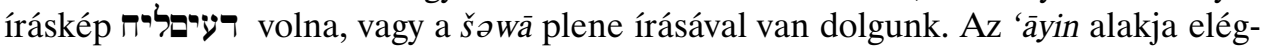
gé archaikus, a palmyrai írásban használt betúforma arameus előzményére emlékeztet. A palmyrai díszírás jelformáját ôrzi a semka $\theta$. Utána a felirat készítője valamilyen más betút akart írni s elôször egy $45^{\circ}$-ban balra dúló karcolást tett, majd ezt keresztül húzta a lāme $\delta$ szárának alsó részével. Nehezen azonosítható a szó utolsó betúje is, amely egy egyenlőtlen szárú V-re emlékeztet. A hẹe $\theta$ írásjel a kurzív palmyrai írásban $\mathrm{N}$ alakú volt, azonban a nippuri varázstálak arameus feliratain ennek már megjelenik olyan változata, amelynél a baloldali függő́leges szár erôsen megrövidül, csaknem eltúnik. ${ }^{6}$ Ennek a betúformának lehet a változata a szóban forgó írásjel, amelyet tehát nagy valószínúséggel ḥē $\theta$-nek határozhatunk meg.

Magyarázatot igényel a következő két írásjel is. Az első kétségtelenül egy yō $\delta$ ot tartalmazó ligatúra, amelyet formai szempontból lehetne zy-nek olvasni. Azonban a palmyraiban a zy vonatkozó névmás hangalakja $d i$, írásképe $d y$ volt, s a feliratokon mindig így fordul elő. Nyelvtörténeti szempontból tehát elesik e ligatúra $z y$ olvasata. A nehézségen ismét a nippuri varázstálkák feliratainak írása segít át. Ebben ugyanis a dāle $\theta$-nek olyan változata jött létre, amelynek feje teljesen elcsökevényesedett s így a betú egy kissé ívelő függóleges szárból állt. Ez a betúforma nyilvánvalóan igen alkalmas volt arra, hogy a gyakran előforduló $d y$ ligatúrában használják a kurzív írásban.

A másik nehézséget egy mandula alakú, alul nyitott, széles betú okozza, amelyhez hasonló a 3. sorban is megfigyelhetô. A kettő között az a különbség, hogy a 2. sorban láthatónak a baloldali része alul szögletesen befelé, a 3. sorban használtnak pedig éles szögben kifelé hajlik el. Ilyen alakú betúk a palmyrai lapidáris írást használó feliratokon nem fordulnak elő, azonban elózményeik megtalálhatók a mīm és a $q \bar{o} f$ formájában. E két írásjelnél megfigyelhető, hogy felsô szögletük egyre jobban kicsúcsosodik (l. írástáblázat No. 916 mīm, No. 909 qōf), miközben a díszírásban egybeeső alakjuk (l. írástáblázat No. 916 mīm, No. 909 qōf) olyan módon differenciálódik, hogy a mīm baloldali szára alul egyenes marad, a qōfé pedig kifelé hajlik. Az írás kurzívvá válása során ez a tendencia megerősödött s e betúk jobb felsố csúcsa még inkább megnyúlt, s baloldali száruk kifelé illetve befelé hajlása pedig éles szögú töréssé vált. E fejlődés értelmében a 2. sorban olvasható betû́t mīm-nek, a 3. sorban láthatót pedig $q \bar{o} f$-nak határozhatjuk meg.

A 2. sor utolsó betúje kurzív tāw. A fentebb tárgyalt ${ }^{\top}$ ד szó írásképe alatt pont figyelhetố meg. Ez valószínúleg szóelválasztó jel, amely más palmyrai feliratokon is

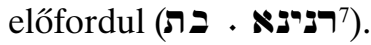

\footnotetext{
${ }^{5}$ F. Rosenthal: i. m. 13.

${ }^{6}$ F. Rosenthal: i. m. 11 (írástáblázat).

${ }^{7}$ H. Jensen: Die Schrift in Vergangenheit und Gegenwart. ${ }^{2}$ Berlin 1958. 296 (Abb. 283).
} 
3. sor. E sor jellegzetessége, hogy a szóhatárokat a szavak utolsó betúje alá tett ponttal vagy vonással csaknem minden esetben jelöli. A sor elején olvasható wāw a díszírásban használt alakváltozatot reprodukálja. A hē erôsen kurzív, függóleges szára vízszintes lett. A $b \bar{e} \theta$ a díszírás változatát követi, a lāma $\delta$ a kurzív változatban jelenik meg. A riūp szóban két érdekes jelenség figyelhető meg. Az egyik jelsor-

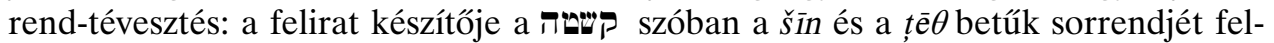
cserélte. Hasonló jelenség más palmyrai feliratokban is elófordul. ${ }^{8}$ A țēe alatt két rövid ferde vonás látható. Lehetséges, hogy ezek a jelsorrend helyesbítését jelzik. A másik figyelemre méltó jelenség az, hogy hē $\sim$ hè $\theta$ jeltévesztés történt: a felirat készítôje először riü alakot vésett be, majd ezt a hêe $\theta$-re félig ráírt hē-vel javította. A szóvégi hē használatára ālaf helyett a palmyraiban több példánk is van ${ }^{9} \mathrm{~s}$ ugyanígy $q s^{\prime} t^{\prime}>q \check{s} t^{\prime}$ hasonulásra is. ${ }^{10}$

Az אב szóban a szóvégi nūn betút a felirat készítóje két, egymáshoz nem csat-

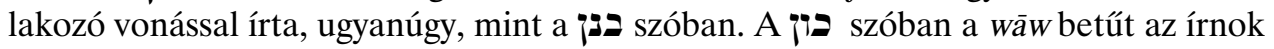
szemmelláthatólag utólag szúrta be a szókezdő kāf bal felsô szára és bal felé nagy ívet alkotó függőleges szára közé.

A felirat végén álló דינד szó már nem fért el a sor végén, ezért jobb felsô szárát a felirat készítője rákarcolta a azt, a szóbelseji nūn-t a dāla $\theta$ bal felsố szára és balra ívelő alsó szárvége közé szorította be, a szóvégi hē betút pedig a dāla $\theta$ alá karcolta be. A dāla $\theta$ eredetileg függóleges szára kb. $140^{\circ}$-kal jobbra dőlt.

Nyelvi megjegyzések:

1. sor. A ت ב szó ‘síremlék' jelentésben a palmyrain kívül a birodalmi arameusban, a héberben és a nabateusban is használatos. ${ }^{11}$ A palmyrai sírfeliratok kezdeté-

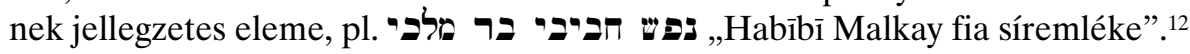

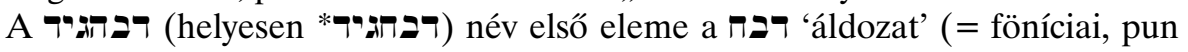

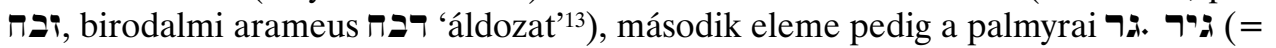

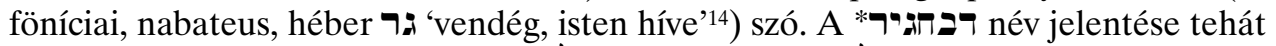

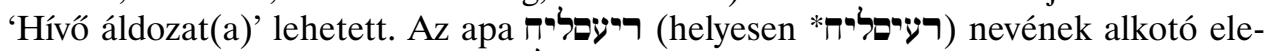

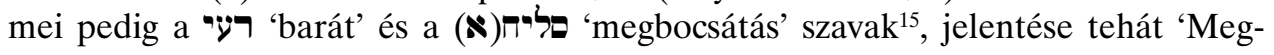
bocsátás barátja' lehetett.

A מת szó a מות 'meghalni' ige perf. sg. 3. szem. alakja.

${ }^{8}$ F. Rosenthal: i. m. 13 (pl. קלקים, helyesen קליקה).

${ }^{9}$ F. Rosenthal: i. m. 21.

${ }^{10}$ F. Rosenthal: i. m. 38.

${ }^{11}$ Ch.-F. Jean-J. Hoftijzer: Dictionnaire des inscriptions sémitiques de l'ouest. Leiden 1965. 183.

${ }^{12}$ H. Jensen: i. m. 296 (Abb. 282).

${ }^{13}$ Ch.-F. Jean-J. Hoftijzer: i. m. 71.

${ }^{14}$ Ch.-F. Jean-J. Hoftijzer: i. m. 53.

${ }^{15}$ Ch.-F. Jean-J. Hoftijzer: i. m. 281, W. Gesenius-F. Buhl: Hebräisches und aramäisches Handwörterbuch über das Alte Testament. ${ }^{17}$ Leipzig 1921. 545. 
3. sor. A חברל név a palmyrai nyelv héber eredetû elemei közé tartozik, mint

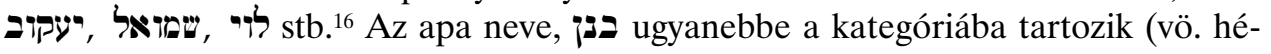
ber בניתי, minai $2{ }^{17}$ ).

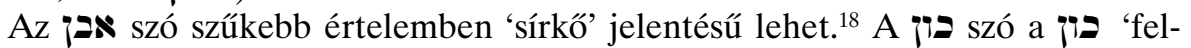
állítani' ige perf.sg.3.szem.alakja. Feltúnő az אבכן בין רבה szavak szórendje a várható בין אבו דנה ל helyett.

E megjegyzések alapján a felirat következóképpen értelmezhető:

1. sor Síremléke

2. Debahgirnak, Re'salih fiának, aki meghalt

3. és Hēbel, Benin fia, az íjász állíttatta ezt a sírkövet.

A felirat szövege, amely síremlékról illetve sírkőról beszél, felveti azt a kérdést, hogy a tárgyalt feliratnak mi volt a tulajdonképpeni funkciója. Tartalmi szempontból ugyanis kétségtelenül sírfelirat, azonban alaki és kivitelezési szempontból ez kevéssé látszik valószínúnek. Ha ugyanis ezt a feliratot valóban egy agyagtáblába karcolták be, mint az anyaga felgyúrődése alapján valószínúnek látszik, akkor semmiképpen sem lehet azonos a szövegében említett sírkővel. Ez az ellentmondás csak úgy oldható fel, ha feltesszük, hogy a ránk maradt agyagtábla fogalmazvány volt, amelynek alapján vésték azután a sírkőbe a végleges szöveget. Ez a jellege egyúttal jól magyarázná az írás kurzív jellegét (a sírköveken használt lapidáris helyett), továbbá a kivitelezés hevenyészett voltát és a benne előforduló íráshibákat is. Ha a feltevés helyesnek bizonyul, akkor az egyetlen ránk maradt palmyrai fogalmazvánnyal állunk szemben. ${ }^{19}$

${ }^{16}$ F. Rosenthal: i. m. 98.

${ }^{17}$ W. Gesenius - F. Buhl: i. m. 105.

${ }_{18}$ Ch.-F. Jean-J. Hoftijzer: i. m. 2.

${ }^{19}$ Ha figyelmesen megvizsgáljuk a felirat fényképét, akkor jobb alsó sarkában egy jobb kéz négy ujjának lenyomatát figyelhetjük meg rajta. Ennek létrejötte csak úgy képzelhető el, ha anyaga valóban anyag volt s az a felirat bekarcolása idején még nem szilárdult meg teljesen. Az ujjlenyomatok az átlagos természetes nagyságnál lényegesen kisebbek, így a feliratos agyaglap nagysága a valóságban legalább egyharmadával nagyobb lehet a fényképnél, amelynek mérete vízszintes irányban $21,8 \mathrm{~cm}$. 